https://helda.helsinki.fi

\title{
The International Co-operative Alliance and the Consumer pÿCo-operative Movement in Northern Europe, c. 18601939
}

\section{Oerskov, Frederik Forrai}

2019-08-08

Oerskov , F F 2019 , ' The International Co-operative Alliance and the Consumer pÿCo-operative Movement in Northern Europe, c. 18601939 ', Scandinavian Journal of History , vol. 44 , no. 4 , pp. 531-533 . https://doi.org/10.1080/03468755.2019.1579424

http://hdl.handle.net/10138/304886

https://doi.org/10.1080/03468755.2019.1579424

Downloaded from Helda, University of Helsinki institutional repository.

This is an electronic reprint of the original article.

This reprint may differ from the original in pagination and typographic detail.

Please cite the original version. 
Review of:

Mary Hilson

The International Co-operative Alliance and the consumer co-operative movement in northern Europe, c. $1860-1939$

Manchester University Press, 2018

194 pages, $£ 80.00$

As the US Inquiry on Co-operative Enterprise in Europe reported to President Roosevelt in August 1936, it estimated that the percentages of households in which at least on member was part of a consumer co-operative in the Nordic countries ranged from above twenty per cent in Norway to more than fifty per cent in Finland (162). The numbers are difficult to verify, according to Mary Hilson, yet make visible the immensity of the co-operate movement in Scandinavia during the late interwar period. Nonetheless, prior to Hilson's book historians have largely ignored the history of this movement-at least from perspectives going beyond the frameworks of nation-bound histories.

This is exactly the perspective Hilson takes up in The International Co-operative Alliance and the consumer co-operative movement in northern Europe, c. 1860-1939. She does it well. The study convincingly situates the co-operative movements of Denmark, Sweden, Finland, and - although less extensively-Norway in the various politics and practices of the International Co-operative Alliance (ICA). Following Kevin Callahan's work on the Socialist International, Hilson suggests that also the ICA was an "inter-national" institution (8); that is to say: nation states mattered institutionally, politically, and practically, also in this transnational framework. As for the co-operative movement, this seems to suggest that in different national contexts and due to differing social realities and historical trajectories, understandings of co-operation and its ideal organizational make-up varied a great deal. The ICA, from Hilson's point of view, became an arena suited not only for the transformation of national conceptions of co-operation through exchanges of ideas and practices but also for the assertion of those conceptions internationally and domestically.

Out of this methodological framework arises the book's overarching questions: What was the nature of co-operation perceived to be? - And how did contemporary actors struggle over this oft-contested concept, which harbored multifarious political, economic, and social interpretations? Such struggles, as Hilson's study convincingly illustrates, become particularly evident when seen from a transnational perspective. This is especially clear in the second half of the book, which traces the institutional politics and struggles over different ideological visions of co-operation, as seen from the point of view of Nordic actors at intersecting international, regional, and national levels. Doing so, it treats these actors as representing and developing a particular Nordic approach to co-operation-thus, seeing the specificities of the co-operative movement in the Nordic countries as, at least in part, an example of successful Nordic collaboration-but also as actors with oft-diverging ideals and interests, within the region and the individual nation states alike. 
As for the latter, the nature of Finnish co-operation proved particularly factional, as the legacy of the Finnish civil war as well as social, political, and linguistic distinctions all paved the way for rather strong animosity during the interwar years between Suomen Osuuskappojen Keskuskunta (SOK) and Kulutusosuuskuntien Keskusliitto (KK), the country's two rival co-operative organizations. Contacts with other Scandinavian associations as well as recognition within the ICA became important ways to gain legitimacy in this domestic struggle (e.g. 87).

The book's first chapter provides the historical roots of the consumer co-operative movement in Northern Europe, discussing the introduction of co-operative visions and practices to the Nordic countries in their European context as well as outlining the organizational nature of the various Nordic consumer co-operative movements. One of the most remarkable strengths of the book is the way in which it conceptualizes these national movements and their organizational dynamics into the transnational arena constituted by the ICA. This contextualization occur throughout the book but especially in chapters two and three, which deal with the practices as well as the political struggles of co-operative internationalism with a focus on the contributions and positions of the Nordic organizations.

Especially the stress put on political neutrality served to unite the Nordic co-operative organizations, Hilson argues in chapter three, into a distinctive bloc within the ICA as the interwar years wore on and the debates about the nature of co-operation loomed large within the organization. Thus, in opposition to continental European and Soviet representatives - seeing co-operation as a social democratic or socialist principle, respectively, challenging capitalist modes of exchange - the Scandinavian approach was mostly pragmatic, insisting that "co-operation was a movement defined by its business principles alone" (97). Chapter four exemplifies the fruits of this approach by tracing the early history of Nordisk Andelsforbund (NAF) - the "one conspicuous success" in terms of international trade organized cooperatively (110). While originally perceived, at least by some of its founding figures, as a means for regional peace after the 1905-breakdown of the Swedish-Norwegian union, NAF was increasingly thought of as a pragmatic and effective way to deal with international trusts and cartels and align the interests of consumers and producers.

Hilson aptly compares the relative success of NAF with the relative failure of a more ambitious attempt to organize international co-operative trade under the auspices of the ICA: The International Cooperative Wholesale Society (the ICWS). Whereas "the example of NAF fits with the interpretation that support for international co-operative trading was a pragmatic strategy for the co-operative unions of small states, motivated above all by the practical difficulties of securing scarce commodities in disrupted markets," (125) most initiatives proposed within the ICWS faltered on large and small state movements carrying different interests and visions. According to Hilson, many members saw the English Co-operate Wholesale Society, which took up a dominating position within the ICWS, as a particular hindrance to the organization's development into a significant trade-coordinating agency.

NAF preceded the ICWS, and many co-operators saw in the former a model for the latter to emulate. However, at least some Scandinavian co-operators were skeptical about the applicability of the regional structure of NAF to the international aspirations of the ICWS (117). Yet, as Hilson shows in chapter five, both the success of NAF and the prominence of co-operation as a whole became integral to the notion of a Nordic "middle way," crystalizing both abroad and within the Scandinavian countries 
during the 1930s. Nordic co-operation, Hilson argues, came to signify a bridging of societal divisions between farmers and workers; a modernization of agriculture and retailing; and an effort to make the capitalist economy function more smoothly (136). Especially the last point made Nordic co-operation, with the overall insistence on practical issues and political neutrality to which it was associated, attractive as a reformist approach to the crisis-ridden capitalist economic system of the Great Depression (150-2). What becomes clear when reading Hilson's book is that this particular regional brand of co-operation could hardly have been articulated so strongly, nor is it likely that its internal divergences could have been reconciled so relatively easily, had it not been for the transnational forum provided by the ICA. Here, writes Hilson, "they defended the principle of co-operative political neutrality, and in doing so argued for a vision of co-operation that was defined above all by its focus on practical, commercial aims" (166). This vision goes a long way to explain President Roosevelt's abovementioned interest in the Nordic co-operative movement.

Frederik Forrai Ørskov, Doctoral Candidate, University of Helsinki 